\title{
ABDOMINAL COCOON SYNDROME IN A 13-WEEKS PREGNANT WOMAN
}

\author{
Fatima Palacio-Lopez', Maria-del-Carmen Garcia-Blanco', Leslie-Marisol Gonzalez- \\ Hermosillo2, José-Alfredo Zuñiga-Montiel33, Ernesto Roldan-Valadez ${ }^{4,5}$ \\ 1 - Department of Radiology, Hospital Angeles Acoxpa. Mexico City, Mexico. \\ 2 - Escuela de Medicina, Universidad de Guadalajara. Jalisco State, Mexico. \\ 3 - Division of Gynaecology, Hospital Angeles Acoxpa. Mexico City, Mexico. \\ 4 - Hospital General de Mexico "Dr Eduardo Liceaga". Mexico City, Mexico.
}

5 - I.M. Sechenov First Moscow State Medical University (Sechenov University), Department of Radiology. Moscow, Russia.

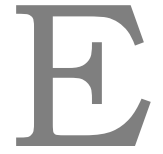

ncapsulating peritoneal sclerosis, also known as abdominal Cocoon syndrome (ACS) is a rare condition presenting with small-bowel obstruction due to a thick fibrous membrane encasing portions of the intestine. We present the case of a 29-years-old pregnant woman referring to abdominal pain in the last three days. Her past medical and surgical history was unremarkable, and she had never complained of similar symptoms ever before; she had no history of previous abdominal operations or medication. On clinical examination, the abdomen was tender and distended; the patient was pregnant; the US was ordered, and analysis revealed a 13-weeks old fetus.

This report aimed to evaluate the radiological and clinical characteristic of ACS in a pregnant patient using MRI.

Keywords: encapsulating peritoneal sclerosis, peritoneal encapsulation, abdominal cocoon syndrome.

Corresponding author: Maria-del-Carmen Garcia-Blanco, e-mail: vacosta313@gmail.com, Ernesto Roldan-Valadez, e-mail: ernest.roldan@usa.net

For citation: Fatima Palacio-Lopez, Maria-del-Carmen Garcia-Blanco, Leslie-Marisol GonzalezHermosillo, José-Alfredo Zuñiga-Montiel, Ernesto Roldan-Valadez. Abdominal cocoon syndrome in a 13-weeks pregnant woman. REJR 2021; 11(3):198-203. DOI: 10.21569/2222-7415-2021-11-3-198203.

Received: $\quad$ 26.06.21 $\quad$ Accepted: $\quad 30.08 .21$

\section{СИНАРОМ АБАОМИНААЬНОГО ॥КОКОНА॥ У БЕРЕМЕННОЙ ЖЕНЩИНЫ HA CPOKE 13 HEAEAb}

\author{
Фатима Па^асио-^опес', Мария-Аель-Кармен Гарсия-Бланко', Аесли-Марисоль \\ Гонсалес-Эрмосильо2, Хосе-Альфррело Зунига-Монтьель ${ }^{3}$, \\ Эрнесто РолАан-Ва^алес 4,5
}

1 - Отдемение мучевой диагностики больницы Angeles Acoxpa. Мехико, Мексика. 2 - Университет Гвадалахары. Штат Халиско, Мексика.

3 - Отдемение гинекологии, больница Angeles Acoхра. Мехико, Мексика.

4 - Генеральная больница Мексики "Dr Eduardo Liceaga". Мехико, Мексика.

5 - Первый МГМУ им. И.М. Сеченова Минздрава России (Сеченовский Университет). г. Москва, Россия. 


\section{RUSSIAN ELECTRONIC JOURNAL OF RADIOLOGY}

K

нкапсулирующий перитонеальный склероз, так же известный как синдром абдоминального "кокона", представляет собой редкое заболевание, проявцяющееся непроходимостью тонкой кишки из-за наличия толстой фиброзной мембраны, покрывающей отделы кишечника. Представлен клинический случай 29-метней беременной женщины с жалобами на боль в животе в течение последних 3-х дней, без отягощенного анамнеза, пациентка ранее никогда не жаловалась на подобные симптомы. При клиническом осмотре живот болезненный и увеличенный в объёме. При УЗИ определялась беременность, 13-недельный плод.

Данный клинический случай демонстрирует клинические, рентгенологические и МРТпризнаки синдрома «абдоминального кокона" у беременной пациентки.

КАючевые слова: инкапсулирующий перитонеальный скмероз, перитонеальная инкапсумяция, синдром абдоминального "кокона".

Контактный автор: Мария-дель-Кармен Гарсия-Бланко, e-mail: vacosta313@gmail.com; Эрнесто Ролдан-Валадес, e-mail: ernest.roldan@usa.net

Для иитирования: Фатима Паласио-Аопес, Мария-дель-Кармен Гарсия-Бланко, ИеслиМарисоль Гонсалес-Эрмосильо, Хосе-Альфредо Зунига-Монтьель, Эрнесто Ролдан-Валадес. Синдром абдоминального "кокона" у беременной женшины на сроке 13 недель. REJR 2021; 11(3):198203. DOI: 10.21569/2222-7415-2021-11-3-198-203.

Статья получена: $\quad 26.06 .21 \quad$ Статья принята: 30.08 .21

I ntroduction.

Abdominal cocoon syndrome (ACS) is a rare condition causing small bowel obstruction; it may present the first time in an emergency without prior significant medical history $[1,2]$. ACS, also known as sclerosing peritonitis, is generally regarded as a chronic condition. The small bowel is partially or totally encased by a thick fibro-collagenous membrane that gives a cocoon-like appearance [3]. Other studies report that ACS is an acquired condition caused by an inflammatory process that is not yet completely understood [1].

In this report, we present the case of a pregnant woman in whom imaging findings using MRI (to avoid excessive ionising radiation because of pregnancy) allowed a diagnosis of ACS. We present the clinical vignette with a brief, updated review of the medical literature.

\section{Case presentation.}

A 29-years-old pregnant woman presented to the emergency department, referring to abdominal pain in the last three days. Her past medical history referred irritable bowel syndrome, and her surgical history was unremarkable; she had never complained of similar symptoms ever before and did not have a history of previous abdominal operations or medication.

The patient began with pain in the epigastrium and radiated to both hypochondria. The pain was burning, stabbing and intermittent. Clinical examination revealed a mass in the right hypochondrium and hypogastrium, positive rebound, rigid ab- domen, no peristalsis and abdominal distension; the patient was pregnant; an abdominal US examination showed clumping of small bowel loops in the right and left inferior quadrants (Fig. 1 A-B). Plain abdominal X-ray showed small bowel type air-fluid levels; findings of laboratory studies were within normal limits (Fig. 2).

Non-enhanced MRI of the abdomen was performed, showing a cluster of small bowel loops in the lower abdomen and the pelvic region anteromedial to the mesocolon with a surrounding sac. The entire small bowel was clumped together within a sclerosing membrane like a cocoon; the large bowel loops appeared outside the sac (Fig. 3 A-F). Based on the imaging findings, a diagnosis of sclerosing peritonitis or cocoon abdomen syndrome without bowel obstruction was made. Because the patient did not present intestinal obstruction and the condition remitted, she was discharged from the hospital, and continue her follow-up in the gynecology division of hospital.

Discussion.

Historical data.

The existence of an abnormal membrane encapsulating the intestine has been reported since 1968 [4]. However, reports from a century ago termed this entity as peritonitis chronica fibrosa incapsulata to describe a membrane encasing the intestine [5]. Foo first introduced the term cocoon syndrome in 1978 [5].

Clinical relevance of this report.

Knowing about ACS is necessary for clinicians attending the emergency room. This clinical 

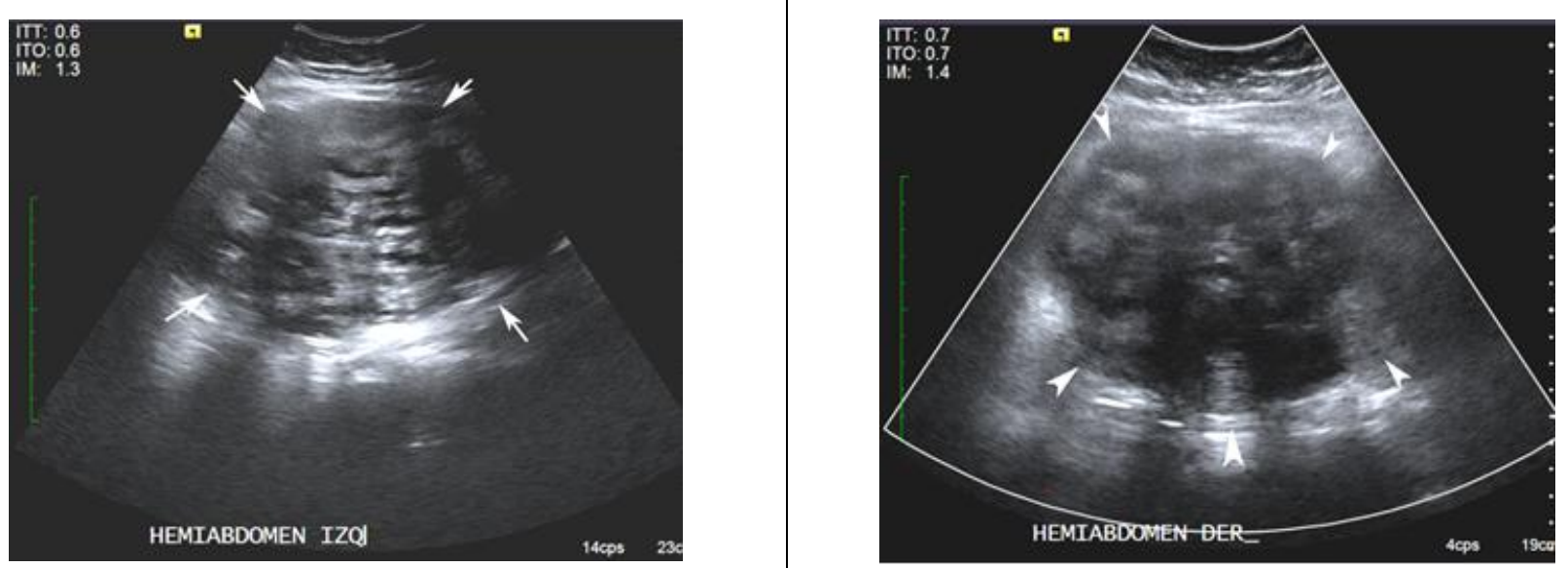

Fig. 1 a (Рис. 1 a)

Fig. 1 b (Рис. 1 б)

\section{Fig. 1. Ultrasound, abdomen.}

Abdominal US examination showed clumping of small bowel loops (white arrows and head arrow) in the right and left inferior quadrants.

\section{Рис. 1. Узи брюшной полости.}

УЗИ брюшной полости демонстрирует скопление петель тонкой кишки (белые стрелки) в правом и мевом нижних квадрантах.

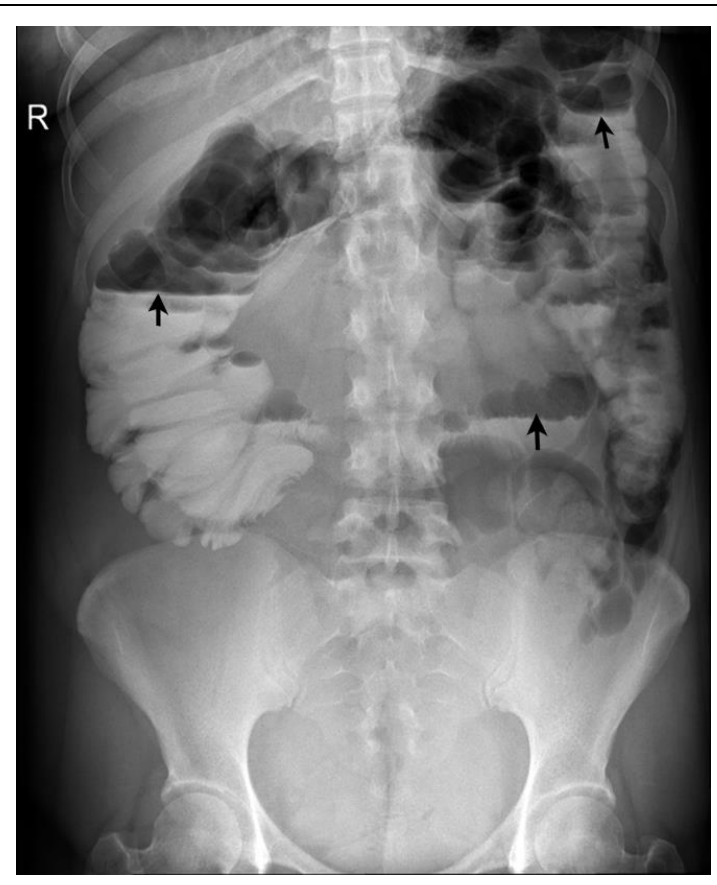

Fig. 2 ( Pис. 2)

\section{Fig. 2. X-Ray, abdomen.}

Examination showed air-fluid levels (black arrows) and dilated small bowel loops.

\section{Рис. 2. Обзорная рентгенограмма органов брюшной полости.}

Уровни газа и жидкости (черные стрелки) и расширенные петли тонкой кишки. entity may have an unusual clinical presentation and be picked up initially as perforated viscus or internal herniation and is not often suspected preoperatively. It also sometimes presents as frank peritonitis with systemic signs and radiologic features mimicking an internal herniation of the bowel [6]. In many cases, ACS remains asymptomatic [4].

\section{Aetiology.}

The aetiology is currently unknown, and some authors propose that, because there is no evidence that ACS's membrane is formed due to an inflammatory process, the disease is considered congenital [7]. On the other hand, other studies have associated ACS with an infectious process like Mycobacterium Bovis from unpasteurised cow's milk [8].

\section{Classification.}

An additional abdominal cavity membrane report has been described in the literature as encapsulating peritoneal sclerosis or sclerosing encapsulating peritonitis (SEP) [7]. This disease can be either primary or secondary [1]. The primary SEP is the one named idiopathic SEP or ACS; secondary SEP is considered acquired and associated with diverse abdominal conditions. Table 1 presents a summary of the EPS classification.

The case presented was diagnosed as an ACS type 2 , as only the small intestine was encapsulated with free colon segments.

\section{Imaging findings.}

The initial evaluation on admission with an $\mathrm{X}$-ray abdomen supine is non-specific. Computed 


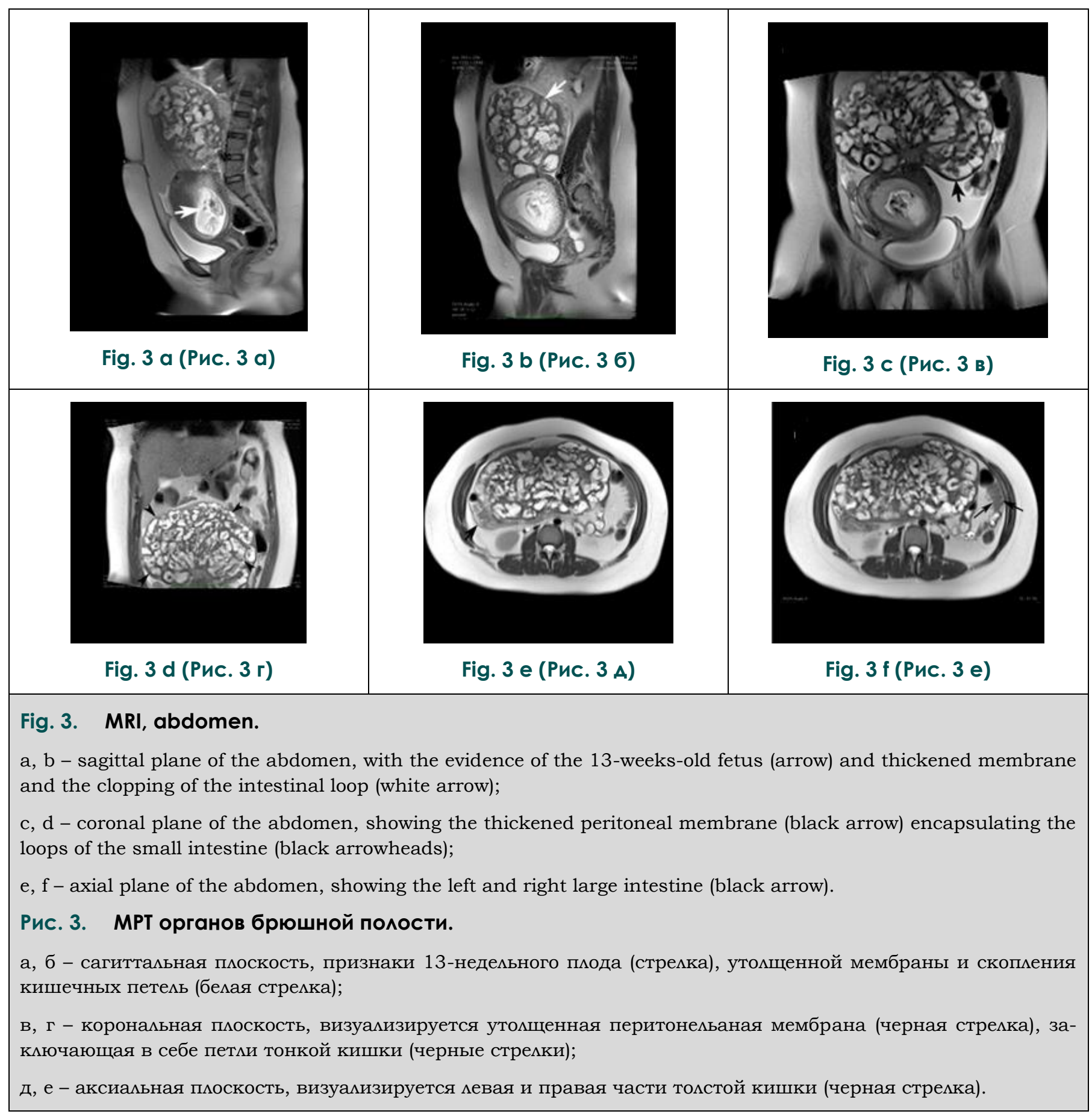

tomography with intravenous contrast (CECT) can depict the entrapment of bowel loops inside the sclerosing layer forming a cocoon [12]. CECT is considered the most useful radiological examination for diagnosing this abnormality for decisionmaking [7]. In the magnetic resonance of previous ACS, imaging bowel loops used to be collected into the centre of the abdomen as a sign of adhesions enhanced thickened peritoneum with calcifications and ascites into the omentum or between bowel loops [4].

Differential diagnosis.

Differential diagnosis should include peritoneal encapsulation, which is a development anomaly where the whole of the small bowel is encased [13]. Other differential diagnosis includes perforated viscus or internal herniation and other causes of abdominal obstruction [14]

\section{Treatment.}

Therapeutic options vary from conservative to open or laparoscopic surgical intervention [4, 15, 11]. Conservative management includes nil per mouth, nasogastric tube and enteral or parenteral nutrition [4, 7, 11]. Patient showing amelioration with this approach could be treated on a chronic basis with medications, such as colchicine, steroids and immunosuppressants [1, 16].

Surgical intervention treatment requires 


\section{RUSSIAN ELECTRONIC JOURNAL OF RADIOLOGY}

\begin{tabular}{|c|c|c|c|}
\hline \multicolumn{4}{|c|}{ Classification of sclerosing encapsulating peritonitis (SEP). } \\
\hline Type & \multicolumn{2}{|l|}{ Clinical features } & References \\
\hline \multirow{3}{*}{$\begin{array}{c}\text { Primary (abdominal cocoon } \\
\text { syndrome) }\end{array}$} & \multicolumn{2}{|l|}{ Type 1, only part of the small intestine is encased. } & \multirow{3}{*}[4,9,7]{} \\
\hline & \multicolumn{2}{|c|}{ Type 2 , the membrane covers the entire small intestine. } & \\
\hline & \multicolumn{2}{|c|}{$\begin{array}{c}\text { Type 3, other organs, such as part of the colon, ovaries, liver, stomach, } \\
\text { or appendix, are also included in the encapsulated viscera. }\end{array}$} & \\
\hline Secondary & \multicolumn{2}{|c|}{$\begin{array}{l}\text { Secondary SEP is highly associated with peritoneal dialysis, intra- } \\
\text { abdominal inflammation, previous abdominal surgery or trauma and } \\
\text { beta-blocker intake. }\end{array}$} & {$[1,9-11]$} \\
\hline \multicolumn{4}{|c|}{ Table №2. Clinical characteristics of ACS, according to Yip and Lee. } \\
\hline \multicolumn{2}{|c|}{ Criteria } & \multicolumn{2}{|c|}{ References } \\
\hline \multicolumn{2}{|c|}{$\begin{array}{l}\text { A. Young female patient without another cause of intestinal obstruction. } \\
\text { B. Medical history of similar episodes associated with spontaneous relief of } \\
\text { symptoms. }\end{array}$} & \multicolumn{2}{|c|}{$[11,16]$} \\
\hline
\end{tabular}

open exploration because of the nature of adhesions and bowel entrapment; excision of the entire sclerosing membrane resulting in entrapment of bowel loops and straightening all entrapped bowel loops to prevent future attacks of bowel obstruction is mandatory [17]. Resection and anastomosis are generally not required unless there is an iatrogenic injury of the bowel during adhesiolysis [18].

\section{Clinical presentation.}

Manifestation of clinical symptoms depends on the extent of the fibrous capsule and has non-specific presentation, making the diagnosis challenging [19]. The most common presentation in Cocoon syndrome is acute abdomen and small-bowel obstruction. Clinically is characterised by an intermittent acute, sub-acute or chronic intestinal obstruction. In contrast, the acute form exhibits stronger symptomatology [4, 20, 21]. The involvement of the stomach, large intestine, liver or other abdominal organs are infrequently occurring [21].

The preeminent clinical manifestations are abdominal pain (colic pain), nausea, vomiting and occasional constipation. In some cases, it has an association with anaemia, low albumin and high C-reactive protein [4]. The small-bowel obstruction results, such as dehydration, electrolytes imbalance, and acute kidney injury with raise creati- nine, are presented [13].

Chronic symptoms are abdominal tension, changes in bowel habits, mild abdominal pain and non-frequently anorexia and weight loss [19]. Abdominal ascites might be detected in longstanding cases [1]. Infrequently present chronic constipation, anorexia, weight loss, intrabdominal masses, perforation or ischemia-related necrosis [14].

On physical examination, there is an increase of bowel sounds with abdominal distention. Non-mobile intestines may cause asymmetric abdominal distention. Besides, in palpation of the abdominal wall, enlarged bowel in the proximal of the adhered section is palpated soft, while the obstructed zone is palpated rigid, flat and painless due to fibrous tissue $[14,19]$

Complications.

Complication includes the entrapment of bowel or twisting leading to vascular insufficiency and a state of low perfusion in the bowel, which can present with signs of peritonitis and, on rare occasions, with systemic sepsis [6].

\section{Conclusion.}

In conclusion, ACS is one of the rare causes of chronic bowel obstruction. Its presentation with sepsis is sporadic but considers this abnormality a possible cause of sub-acute or chronic abdominal pain and small-bowel obstruction. In cas- 


\section{RUSSIAN ELECTRONIC JOURNAL OF RADIOLOGY}

es of emergency presentation, it is found at the time of laparotomy as an unexpected finding. Removal of the sclerosing membrane and straightening up the bowel is the treatment of choice if the bowel on inspection is healthy and viable. In our

\section{References:}

1. Karona P, Bleurakis E, Kastanaki P, Tzouganakis A, Kastanakis $M$ (2021) Abdominal Cocoon Syndrome: An Extremely Rare Cause of Small Bowel Obstruction. Cureus. 2021; 13 (4): e14351. doi:10.7759/cureus. 14351

2. Tannoury JN, Abboud BN (2012) Idiopathic sclerosing encapsulating peritonitis: abdominal cocoon. World $J$ Gastroenterol. 2012; 18 (17): 1999-2004. doi:10.3748/wjg.v18.i17.1999

3. Yamada S, Tanimoto A, Matsuki Y, Hisada Y, Sasaguri Y (2009) Sclerosing encapsulating peritonitis (abdominal cocoon) associated with liver cirrhosis and diffuse large B-cell lymphoma: autopsy case. Pathol Int. 2009; 59 (9): 681-686. doi:10.1111/j.1440-1827.2009.02427.x

4. Allam H, Al Yahri O, Mathew S, Darweesh A, Suliman AN, Abdelaziem S, Khairat M, Toro A, Di Carlo I (2016) The enigma of primary and secondary encapsulating peritoneal sclerosis. BMC Surg. 2016; 16 (1): 81. doi:10.1186/s12893-016-0198-2

5. Machado NO (2016) Sclerosing Encapsulating Peritonitis: Review. Sultan Qaboos Univ Med J. 2016; 16 (2): e142-151. doi:10.18295/squmj.2016.16.02.003

6. Saqib SU, Farooq R, Saleem O, Moeen S, Chawla TU (2021) Acute presentation of cocoon abdomen as septic peritonitis mimicking with strangulated internal herniation: a case report. Surg Case Rep. 2021; 7 (1): 93. doi:10.1186/s40792-021-01179-7

7. Akbulut $S$ (2015) Accurate definition and management of idiopathic sclerosing encapsulating peritonitis. World $J$ Gastroenterol. 2015; 21 (2): 675-687. doi:10.3748/wjg.v21.i2.675

8. Anantha RV, Salvadori MI, Hussein MH, Merritt N (2015) Abdominal cocoon syndrome caused by Mycobacterium bovis from consumption of unpasteurised cow's milk. Lancet Infect Dis. 2015; 15 (12): 1498. doi:10.1016/S1473-3099(15)00438-7

9. Xia J, Xie W, Chen L, Liu D (2018) Abdominal cocoon with early postoperative small bowel obstruction: A case report and review of literature in China. Medicine (Baltimore). 2018; 97 (25): e11102. doi:10.1097/MD.0000000000011102

10. Frost JH, Price EE (2015) Abdominal cocoon: idiopathic sclerosing encapsulating peritonitis. BMJ Case Rep. 2015. doi:10.1136/bcr-2014-207524

11. Solak A, Solak I (2012) Abdominal cocoon syndrome: preoperative diagnostic criteria, good clinical outcome with medical treatment and review of the literature. Turk $J$ Gastroenterol. 2012; 23 (6): 776-779. doi:10.4318/tjg.2012.0500. experience, we recommended MRI to avoid excessive ionising radiation in case of pregnancy. The patient did not present intestinal obstruction, and the condition remitted; she was discharged from the hospital.

12. Gorsi U, Gupta P, Mandavdhare HS, Singh H, Dutta U, Sharma $V$ (2018) The use of computed tomography in the diagnosis of abdominal cocoon. Clin Imaging. 2018; 50: 171-174. doi:10.1016/j.clinimag.2018.03.014

13. Saqib SU, Pal I (2019) Sclerosing peritonitis presenting as complete mechanical bowel obstruction: a case report. J Med Case Rep. 2019; 13 (1): 310. doi:10.1186/s13256-019-2243-O

14. Colak Ş, Bektaş $H$ (2019) Abdominal cocoon syndrome: A rare cause of acute abdomen syndrome. Ulus Travma Acil Cerrahi Derg. 2019; $25 \quad$ (6): 575-579. doi:10.14744/tjtes.2019.48380

15. Singh B, Gupta S (2013) Abdominal cocoon: a case series. Int $J \quad$ Surg. 2013; $11 \quad$ (4): 325-328. doi:10.1016/j.ijsu.2013.02.011

16. Solmaz A, Tokocin M, Arici S, Yigitbas H, Yavuz E, Gulcicek $O B$, Ercetin C, Celebi F (2015) Abdominal cocoon syndrome is a rare cause of mechanical intestinal obstructions: a report of two cases. Am J Case Rep. 2015; 16: 77-80. doi:10.12659/AJCR.892658

17. Kumar M, Deb M, Parshad R (2000) Abdominal cocoon: report of a case. Surg Today. 2000; 30 (10): 950-953. doi:10.1007/s005950070053

18. Li N, Zhu W, Li Y, Gong J, Gu L, Li M, Cao L, Li J (2014) Surgical treatment and perioperative management of idiopathic abdominal cocoon: single-center review of 65 cases. World $J$ Surg. 2014; 38 (7): 1860-1867. doi:10.1007/s00268-014-24586

19. Akbas A, Hactm NA, Dagmura H, Meric S, Altinel Y, Solmaz A (2020) Two Different Clinical Approaches with Mortality Assessment of Four Cases: Complete and Incomplete Type of Abdominal Cocoon Syndrome. Case Rep Surg. 2020; 4631710. doi:10.1155/2020/4631710

20. Yang CS, Kim D (2016) Unusual intestinal obstruction due to idiopathic sclerosing encapsulating peritonitis: a report of two cases and a review. Ann Surg Treat Res. 2016; 90 (4): 231-234. doi:10.4174/astr.2016.90.4.231

21. Sovatzidis A, Nikolaidou E, Katsourakis A, Chatzis I, Noussios G (2019) Abdominal Cocoon Syndrome: Two Cases of an Anatomical Abnormality. Case Rep Surg. 2019: 3276919. doi:10.1155/2019/3276919. 